\title{
Watermelon landrace seedling establishment and field performance in response to differing water regimes
}

\author{
Modi A. T.* and Zulu N. S. \\ School of Agricultural, Earth and Environmental Sciences, University of KwaZulu-Natal, P/Bag X 01, Scottsville, 3209, \\ Pietermaritzburg 3209 South Africa.
}

Accepted 5 April, 2012

\begin{abstract}
Wild watermelon (Citrullus lanatus) is an indigenous crop whose agronomic potential has not been well investigated in South Africa. However, the country has a significant amount of the crop's germplasm in the form of landraces. Three local landraces of watermelon were compared for seedling establishment and production under controlled and dry land field conditions. The objective of the study was to determine watermelon landrace seedling establishment, plant growth and fruit production under controlled environment using different growth media (pine bark, sand and a mixture of pine bark and sand (1: $1(\mathrm{v} / \mathrm{v})$ and dry land field conditions in response to planting dates from September, 2008 to January, 2009. Results showed that seedling establishment was significantly affected by growth medium. Pine bark produced significantly at $(P<0.05)$ larger seedlings than the mixture or sand alone due to its capacity to hold water better than the other two media. Seedling production of wild watermelon did not improve significantly when the field capacity of the growing medium was increased above $50 \%$ suggesting potential drought tolerance for the crop. Early field planting was found to be associated with larger fruit size in spite of low soil water availability early in the season, another evidence for potential drought tolerance.
\end{abstract}

Key words: Field capacity, planting date, seedling establishment, water use.

\section{INTRODUCTION}

Indigenous vegetables play a noteworthy role in human nutrition (Fox and Norwood, 1982; Renault and Wallender, 2000). For thousands of years, the indigenous people of South Africa relied heavily on the gathering of edible plants for survival (Fox and Norwood, 1982). Many social studies of the life and customs of the black tribes of Southern Africa have been undertaken since the early 1900s but there have been few records of how the indigenous crops respond to agronomic management practices (Modi, 2007a). However, evidence for the role of wild vegetables in food security has been shown elsewhere in Africa (Uusika et al., 2010). Agricultural scientists and development communities in South Africa have largely neglected indigenous vegetables traditionally used by native Africans. In a country that is

\footnotetext{
Corresponding author. E-mail: modiat@ukzn.ac.za.
}

confronted by HIV/AIDS, malnutrition and poverty, these vegetables should be considered as potential sources of micronutrients and vitamins. Water deficit is one of the most important environmental factors restricting plant growth and productivity (Boyer, 1982), because it influence nutrient availability (Colla et al., 2008; Demir et al., 2011). South Africa is a water-scarce country with very limited water available for agriculture (Nnadozie, 2011). Hence, in the context of crop production, water use efficiency is very important since it determines the amount of water required to produce biomass and nutritional content (Modi, 2007b; Zulu, 2009). The concurrent water (Nnadozie, 2011) and malnutrition (Modi et al., 2006) threats have provided a need to study the productivity and nutritional value of under-utilized indigenous and indigenized food crops in South Africa, with the aim of promoting production of more nutritious food from these neglected crops with the same quantity of water, if not less. 
Table 1. Mean climatic data for seedlot provenances compared with Pietermaritzburg, the study site, estimated from Smith (2006).

\begin{tabular}{lclcccl}
\hline Location & Altitude $(\mathbf{m})$ & $\begin{array}{l}\text { Seasonal } \\
\text { rainfall }\end{array}$ & $\begin{array}{c}\text { Mean annual } \\
\text { precipitation }(\mathbf{m m})\end{array}$ & $\begin{array}{c}\text { Mean annual } \\
\text { temperature }\left({ }^{\circ} \mathbf{C}\right)\end{array}$ & $\begin{array}{c}{ }^{\alpha} \text { Drought } \\
\text { occurrence }(\%)\end{array}$ & $\begin{array}{l}\text { Average frost } \\
\text { period (days) }\end{array}$ \\
\hline Centane & $0-600$ & Year round & $800-1000$ & $17.5-20$ & 10 & Frost free \\
Umbumbulu & $0-600$ & Summer & $>1000$ & $20-22.5$ & 10 & Frost free \\
Tugela Ferry & $600-1200$ & Summer & $600-800$ & $17.5-20$ & 10 & Frost free \\
Pietermaritzburg & $600-1200$ & Summer & $800-1000$ & $17.5-20$ & 10 & $1-30$ \\
\hline
\end{tabular}

${ }^{\alpha}$ Drought refers to agricultural conditions when rainfall and temperature result in crop failure and loss of grazing in 10\% of the years (Smith, 2006).

The success of production is determined by seedling establishment, especially, in horticultural crops (Colla et al., 2008; Demir et al., 2011; Gross, 1984).

Environmental conditions during crop growth under field conditions have a potential to reverse or enhance seedling performance. However, there are few studies (Gross, 1984) that traced field crop performance in relation to seedling establishment. The objective of this study was to investigate the response of watermelon landrace (Citrullus lanatus) to different water regimes during seedling establishment and crop growth under dry land field production.

\section{MATERIALS AND METHODS}

\section{Source of indigenous germplasm}

Watermelon landrace seeds were donated by subsistence farmers from different sites in KwaZulu-Natal and Eastern Cape, South Africa. While seeds of watermelon landraces were generally of the same size, the seeds obtained from different localities differed in seed colour. Henceforth, the seed lots will be referred to as 'Brown' (B), 'Dark-Brown' (DB) and 'Very Dark-Brown' (VDB), respectively.

'Brown' (B) seeds were collected from a homestead in Centane, Eastern Cape. Centane is located about $50 \mathrm{~km}$ east of East London, along the coast, on the cool subtropical coastal zone of South Africa. 'Dark Brown' (DB) was collected from a homestead at Tugela Ferry, a semi- arid part of the KwaZulu-Natal midlands. 'Very Dark Brown' (VDB) was collected from a homestead at Umbumbulu, about $40 \mathrm{~km}$ Northwest of Durban, in the warm subtropical coastal zone of South Africa. All seeds were derived from the year 2005/2006 rain-fed summer crop. The collected seeds were used to produce fresh seed lots during the 2006/2007 season at the University of KwaZulu-Natal, Pietermaritzburg $\left(29^{\circ} 35^{\prime} \mathrm{S}\right.$ and $\left.30^{\circ} 25^{\prime} \mathrm{E}\right)$. Weather data for the seed provenances and seed production site differed (Table 1).

\section{Seedling establishment}

To simulate a nursery seedling establishment situation, seeds were planted in seedling trays (Alibaba.com ${ }^{\circledR}$ ) containing different growth media. The growth media were: fine sand $\left(90.57 \mathrm{~cm}^{2} \mathrm{~g}^{-1}\right)$, pine bark (typical nursery material; Bark Enterpises ${ }^{\circledR}$ ) and a 1: $1(\mathrm{v} / \mathrm{v})$ mixture of sand and pine bark. Sand and pine bark were separately analyzed for nutrient content and fertilized with a Hoagland's nutrient solution while their water contents were maintained at 75, 50 and $25 \%$ field capacity (FC), respectively, throughout the growing period (Zulu, 2009). The experiment was designed as a factorial split-plot consisting of three seed lots (B, DB and VDB), three growing media (Sand, Mixture and Pine bark), three water regimes $(75,50$ and $25 \% \mathrm{FC})$, and replicated three times. The experimental block was a 200-celled seedling tray, split into three 60 -celled units of one growing medium each, in which 60 seeds of a particular seed lot were planted, that is, 180 cells were planted and the remainder used as boundaries. The glasshouse used for seedling establishment was kept at $21 / 16^{\circ} \mathrm{C}$ (day/night) respectively, and $60 \% \mathrm{RH}$. Emergence was determined by counting the number of emerged seedlings on days 9,10,11 and 12 after seeding. Six weeks after emergence, seedlings were harvested to determine fresh and oven-dry $\left(60^{\circ} \mathrm{C}\right.$ over $\left.24 \mathrm{~h}\right)$ mass (Modi, 2007b). Plant mass produced per unit of water used was determined by:

[Seedling dry mass/(Seedling fresh mass - Seedling dry mass)] $\times$ 100

\section{Field crop performance}

A dry land (rain-fed) field trial was conducted on a soil of the Oatlands family of the Inhoek form (Soil Classification Working Group, 1991) in Pietermaritzburg on three different planting dates: $25^{\text {th }}$ September, 2008, 23 ${ }^{\text {rd }}$ November, 2008 and $20^{\text {th }}$ January, 2009 representing spring, early summer and late summer, respectively. Before planting, soil analysis was performed and fertilizer application recommended at $50 \mathrm{~kg} \mathrm{ha}^{-1} \mathrm{~N}, 20 \mathrm{~kg} \mathrm{ha}^{-1} \mathrm{P}$ and $0 \mathrm{~kg}$ ha ${ }^{1} \mathrm{~K}$ according to the requirements for dry land production of water melon (Smith, 2006). In anticipation of less than 100\% germination, three seeds were planted per station and one week after emergence seedlings were thinned out to one seedling per station. Thinning process was performed to achieve uniform seedling size and $100 \%$ initial population per plot, at a spacing of $50 \mathrm{~cm}$ within row and $200 \mathrm{~cm}$ between rows (Smith, 2006). Plots were $16 \mathrm{~m}^{2}$ in size, separated by a distance of $2 \mathrm{~m}$ corridors. Each planting date (main plot), was split into three seed lots (B, DB and VDB) (subplots), which were replicated three times. In each sub-plot, the sampling unit consisted of the three middle plants surrounded by border rows. Leaf number and vine length were determined at the $2^{\text {nd }}, 5^{\text {th }}$ and $8^{\text {th }}$ weeks after planting, such that the last sampling occurred at the start of flowering. Fruit yield was determined 135 days after emergence by fruit size and fruit number per plot at senescence. Fruits were graded by size into small $(<2 \mathrm{~kg})$, medium (2 to $5 \mathrm{~kg}$ ) and large (> $5 \mathrm{~kg})$. Gravimetric water content of the soil was determined from the top $30 \mathrm{~cm}$ of each sampling unit every week for 12 weeks by:

$\% \mathrm{w}=[($ Wet mass - Oven dry mass $) /$ Wet mass $] \times 100(2)$

\section{Statistical analysis}

GENSTAT Statistical Package Version 9 was used to perform analysis of variance and to generate values of least significant 


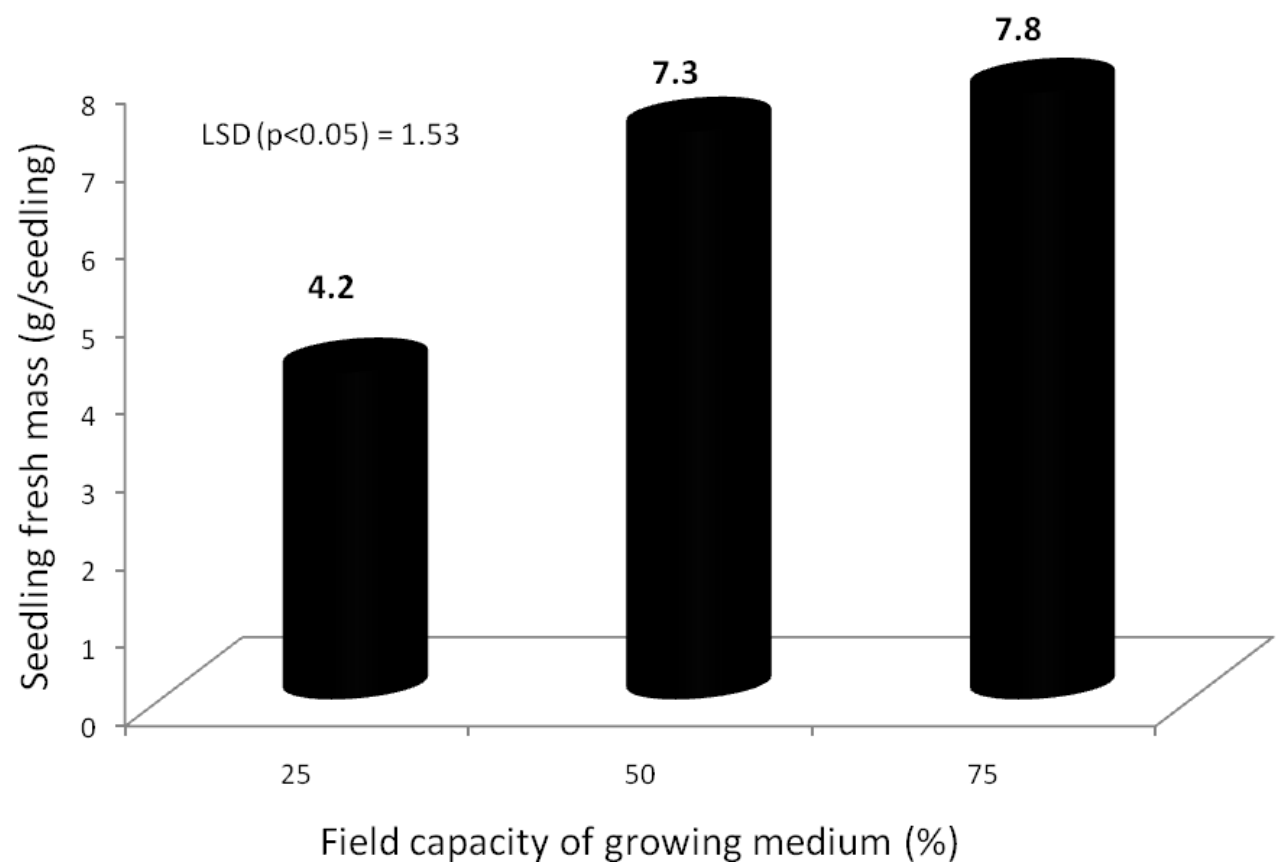

Figure 1. Wild watermelon seedling fresh mass in response to water status of growing medium.

differences, which were used to determine differences between treatments $(P \leq 0.05)$.

\section{RESULTS AND DISCUSSION}

\section{Seedling establishment}

For fresh mass, there were significant $(P<0.05)$ effects of water regimes, seed lots and media, but there was no significant interaction between these factors (Figure 1) under controlled environment conditions. The $25 \%$ FC produced significantly $(P<0.05)$ smaller seedlings than 50 and $75 \%$ FC respectively (Figure 1). The finding that $50 \%$ FC produced seedlings that were not inferior (no significant statistical difference) to those produced with $75 \%$ FC suggests the potential efficiency of the indigenous vegetables used in this study in water use. For dry mass, there were significant $(P<0.05)$ effects of water regimes, seed lots and media, but there was also a significant $(P<0.05)$ interaction of water regime $(F C)$ and media (Figure 2). To understand the effectiveness of each treatment (seed lot, water regime and growth medium) in dry mass production, plant mass produced per unit of water used was taken to represent potential water productivity (Figure 2). The comparison of water regimes, media and seed lot, with respect to seedling fresh mass (Figure 1), followed the same pattern as that of seedling dry mass (Figure 2). Although, seedling fresh mass and dry mass were derived from the same material, it was not a given fact that they should follow the same pattern in terms of their response to treatments. Since plants have high water content and the level of water in a plant will depend on the amount of water in its environment, using dry mass as a measure of plant growth is more reliable than using fresh mass (Salisbury and Ross, 1992). From Figure 2, it was evident that there was no significant difference among seed lots with respect to plant mass produced per unit of water used. Comparison of water regimes showed that although, low water content compromised production, watermelon landraces were capable of performing well under moderate (50\% FC) water content conditions (Figure 2). Sand and the mixture of pine bark and sand showed similar watermelon production trends, which were lower than that of pine bark alone (Figure 2). The results shown in Figure 3 suggest that it would be more efficient to produce seedlings using anyone of the seed lots grown in a pine bark at $50 \%$ FC. These findings are generally in agreement with the previous findings of Condon and Hall (1997) (Gwathmey and Hall, 1992); (Le Roux et al., 1996) and Ludlow and Muchow (1990).

\section{Planting date effects on growth and fruit production}

The crop that was planted early (September) germinated and emerged under low soil moisture conditions (Figure 3 ), but there was a steady increase in soil moisture as the rainfall increased from September to December to reach $\sim 65 \%$ moisture content. The November planting occurred under soil moisture conditions higher than those of the September planting, but lower than those of January planting. The high moisture content at the start of the 


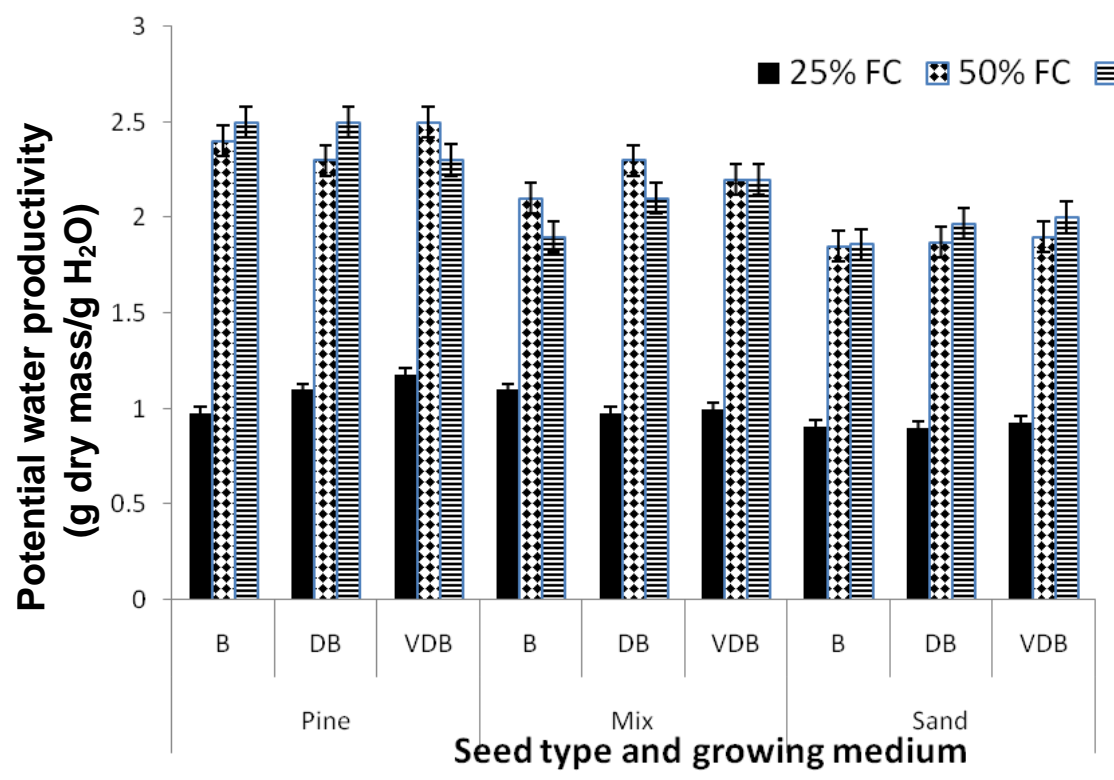

Figure 2. Potential water productivity of three wild watermelon genotype seedlots $(B, D B$ and VDB) grown in three media (Pine = pine bark, Mix = 50: 50 pine bark and sand, and Sand = pure sand) at three different water regimes (25\% FC, 50\% FC and 75\% FC).

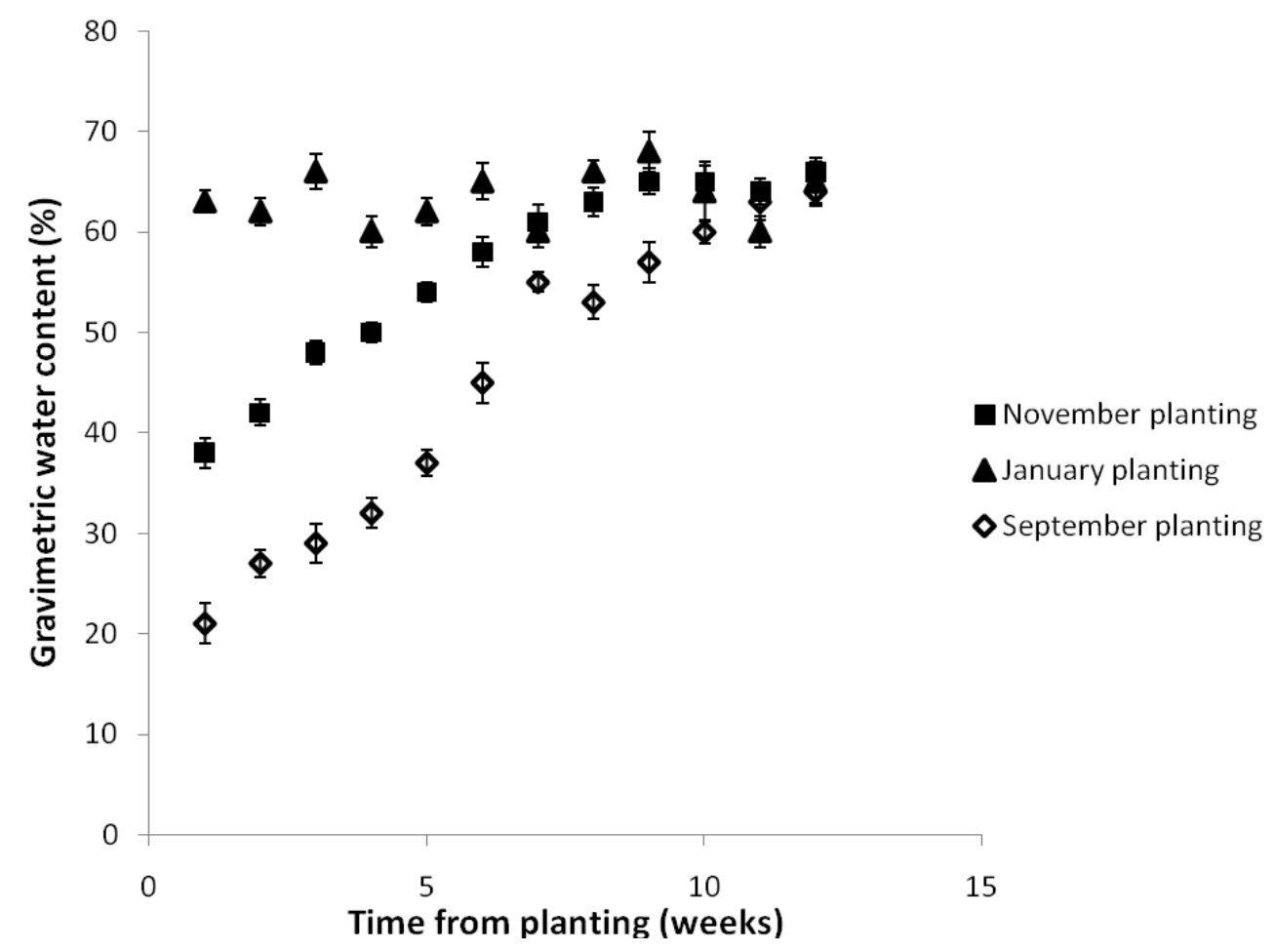

Figure 3. Changes in gravimetric soil water content during the different planting seasons of wild watermelon under dryland field conditions.

November and January plantings were expected toresult in faster seedling emergence; however, there were no significant differences between planting dates or seed lots with respect to field emergence. Despite the lack of differences in emergence, crop growth for the September planting was better sustained by higher soil water content during the period when plants were growing faster in response to increased leaf number (Figure 4). There 


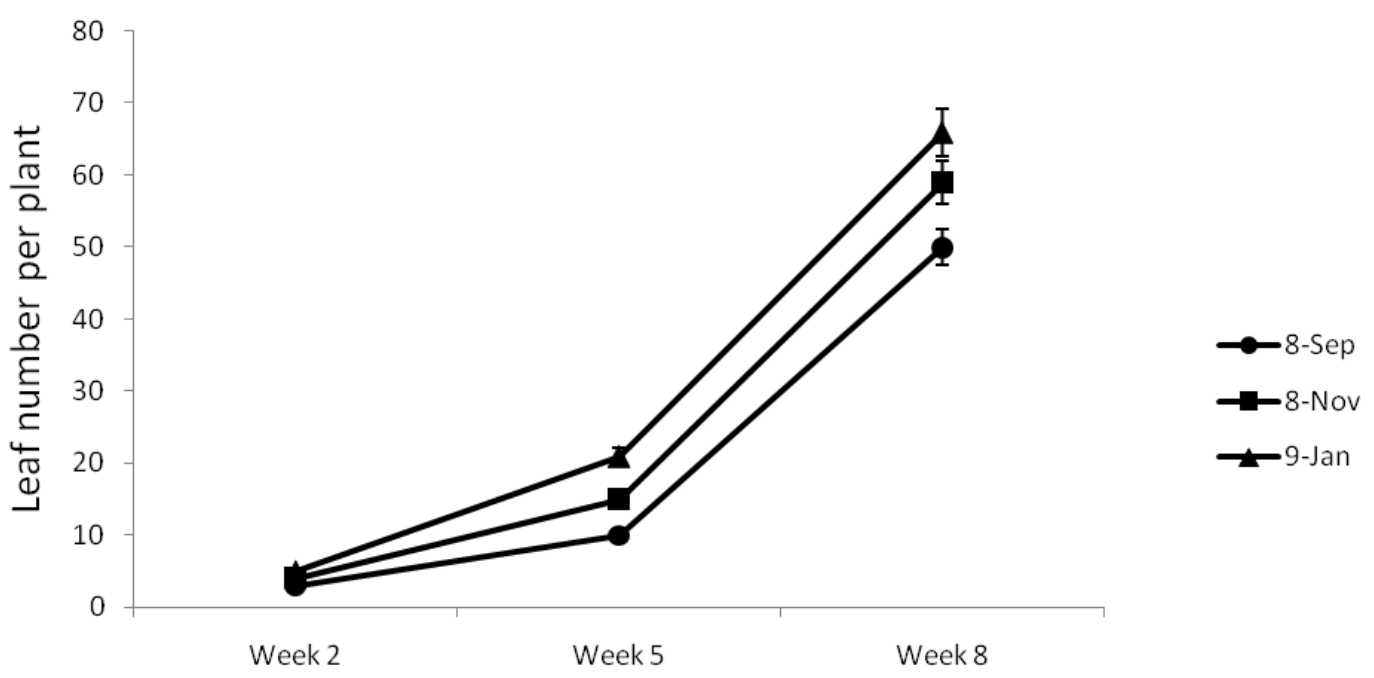

Weeks after planting

Figure 4. Changes in wild watermelon leaf production in response to planting date $\left(8^{\text {th }}\right.$ September, $8^{\text {th }}$ November and $9^{\text {th }}$ January) under rain-fed field conditions.

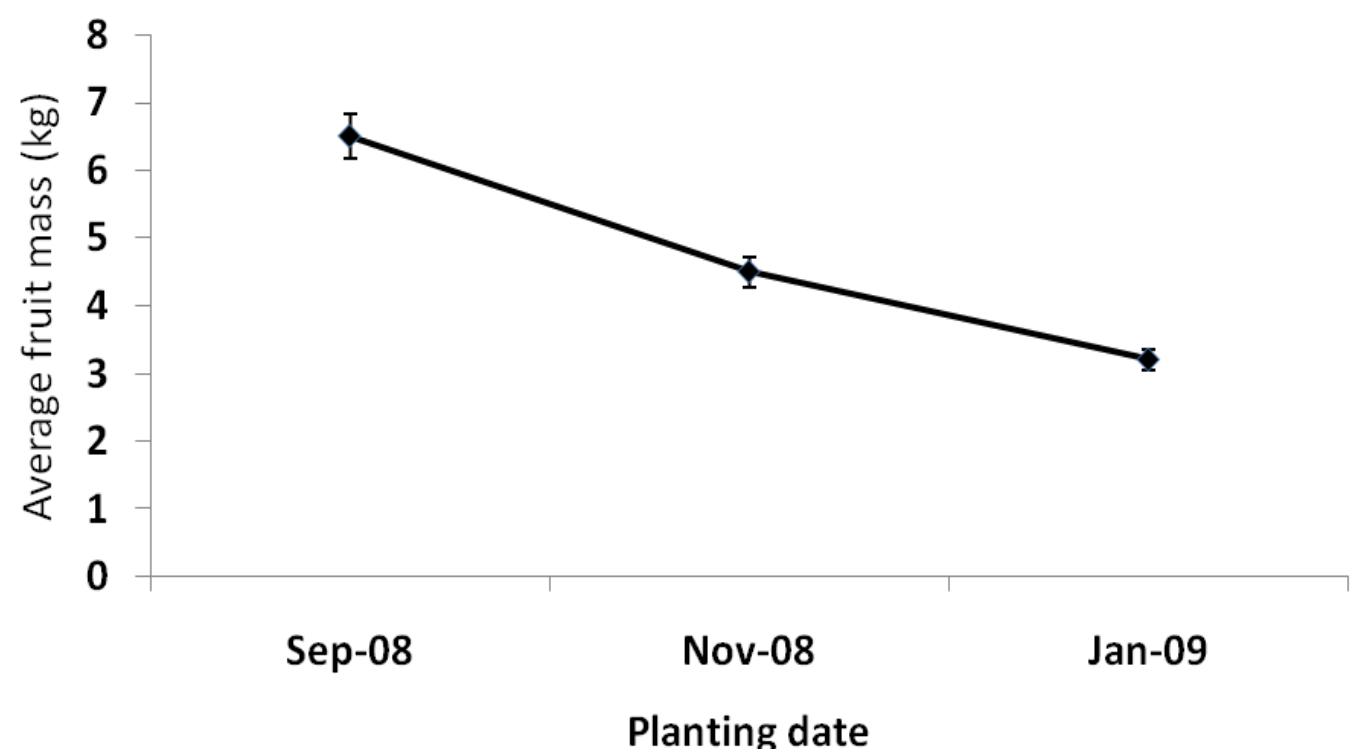

Figure 5. Effect of planting date on average fruit mass of wild watermelon under dry land field conditions.

were significant differences $(P<0.05)$ between seed types, with respect to fruit size (Figure 5). In the context of crop management, the important comparisons were those between planting dates (Figure 5). Despite early September planting being associated with low gravimetric moisture content, early planting was correlated with higher fruit size (Figure 5).

Sensitivity of cucurbits to water and temperature stresses has been reported by Lee et al. (2003) and Moon et al. (2007). Blending of media for seedling production is also a common phenomenon in research for the nursery industry (Choi et al., 2007; Warncke, 1986).
In the present study, blending of pine bark and sand improved seedling emergence under moderate soil water availability, but seedling growth was best supported in the pine bark only medium with $75 \%$ FC. Differences in response to media may have been due to the fact that the mixture of sand and pine bark provided a combination of water availability and temperature that favored seed germination.

Climatic information is necessary for successful planning in agriculture (Yilmaz and Harmancioglu, 2010). Various indices, such as water efficiency indices, thermal indices and heat units, etc, were developed in early 
attempts to relate climatic data more closely to factors such as crop growth rate, yield and production as required for land use planning and crop zonation. These usually involved accumulated temperature, some comparison of rainfall with crop water requirements, and the length of the season with favourable indices (Bidinger and Johansen, 1986). This study relied on naturally occurring climatic conditions to determine the response of wild watermelon to soil water content over three seasons created by planting at different times of the year.

\section{Conclusion}

The study showed that results from controlled and field studies of watermelon landrace response to water deficits indicated that watermelon seedlings were responsive to water stress under controlled environment conditions in that sandy media and $25 \%$ FC reduced seedling growth, but the crop displayed the ability to improve water use under water stress. Crop yield improved under long season conditions, despite low soil water availability at the beginning of the season. The focus of this study was to indicate the response of crop performance to differing water regimes under controlled and natural field conditions. Hence, specific data on traditional crop yield was not reported, and fruit size, which is an index of value by rural people in South Africa, was emphasized. Future studies will focus on agrometeorology, crop modeling and traditional yield.

\section{ACKNOWLEDGEMENT}

This study was funded by the Water Research Commission, Project No.K5 /1771//4.

\section{REFERENCES}

Boyer JS (1982). Plant productivity and environment. Science: 218:443448.

Bidinger FR, Johansen C (1986). Drought research priorities for the dryland tropics. ICRISAT, Patancheru, India.

Chol JM, Ahn JW, Ku JH (2007). Growth and nutrient uptake of tomato plug seedlings influenced by elevated blending rate of perlite in Coir and peatmoss substrates. Hort. Environ. Biotech. 48:270-276.

Condon AG, Hall AE (1997). Adaptation to diverse environments: variation in water use efficiency within crop species, In: L.E. Jackson (ed.) Ecology in agriculture, Academic Press, San Diego, California.pp. 79-116.

Colla G, Rouphael Y,Cardarelli M, Rivera CM, Rea E (2008). Alleviation of salt stress by Arbuscular mycorrhuzae in succhini plants grown at low and high phosphorus concentration. Biol. Fert. Soils 44:501-509.

Demir K, Başak H, Okay FY, Kasim R (2011). The effect of endomycorrhiza (VAM) treatment on growth of tomato seedling grown under saline conditions. Afr. J. Agric. Res. 6:3326-3332.
Fox FW, Norwood-Young M (1982). Food from the veld. Delta Books, Johannesburg. p. 70.

Gwathmey CO, Hall AE (1992). Adaptation to midseason drought of cowpea genotypes with contrasting senescence traits. Crop Sci. 32:773-778.

Gross KL (1984). Effects of seed size and growth form on seedling establishment of six monorcapic perennial plants. J. Ecol. 72:369387

Lee JW, Lee EH, Kim KD, Lee WS (2003). Effects of root zone warming on water and nutrient uptake, and photosynthesis of cucumber grown in a greenhouse. J. Korean Soc. Hort. Sci. 44:635-638.

Le Roux D, Stock WD, Bond WJ, Maphanga D (1996). Dry mass allocation, water use efficiency and ${ }^{d 13} \mathrm{C}$ in clones of Eucalyptus grandis, E. grandis' camaldulensis and E. grandis' nitens grown under two irrigation regimes. Tree Physiol. 16:497-502.

Ludlow MM, Muchow RC (1990). Critical evaluation of traits for improving crop yields in water-limited environments. Adv. Agron. 43:107-153.

Modi M, Modi AT, Hendricks S (2006). Potential role for wild vegetables in household food security: a preliminary case study in KwaZuluNatal, South Africa. Afr. J. Food Agric. Nutr. Dev. 6:1-13.

Modi AT (2007a). Effect of indigenous storage method on performance of taro [Colocasiaesculenta (L.)Schott] under field conditions in a warm subtropical area. South Afr. J. Plant Soil 24:214-219.

Modi AT (2007b). Growth temperature and plant age influence on nutritional quality of Amaranthus leaves and seed germination capacity. Water SA. 33:369-375.

Moon JH, Boo HO and Jang IO (2007). Effect of rootzone temperature on water relations and hormone contents in cucumber. Hort. Environ. Biotech. 48:257-264.

Nnadozie RC (2011). Access to adequate water in post-apartheid South African provinces: An overview of numerical trends. Water SA. 37:339-347.

Renault D, Wallender WW (2000). Nutritional water productivity and diets. Agric. Water Manage. 45:275-296.

Salisbury FB, Ross CW (1992). Plant physiology. Wadsworth Publishing Company, Belmont, Carlifornia, p. 331.

Smith B (2006). The farming handbook. University of KwaZulu-Natal Press, Pietermaritzburg. p. 66.

Uusika NP, Oelofse A, Duodu KG, Bester M, Faber M. (2010). Nutritional value of leafy vegetables of sub-Saharan Africa and their potential contribution to human health: A review. J. Food Comp. Anal. 23:499-509.

Warncke PD (1986). Analysing greenhouse growth substrates by the saturation extraction method. HortSci. 211: 223-225.

Yilmaz B, Harmancioglu NB (2010). Multi-criteria decision making for water resource management: A case of the Gediz River Basin, Turkey. Water SA 36:563-576.

Zulu NS (2009). Wild watermelon (Citrullus lanatus L.) landrace production in response to three seedling growth media and field planting dates. MSc Agricultural Thesis, University of KwaZulu-Natal, Pietermaritzburg, South Africa. 